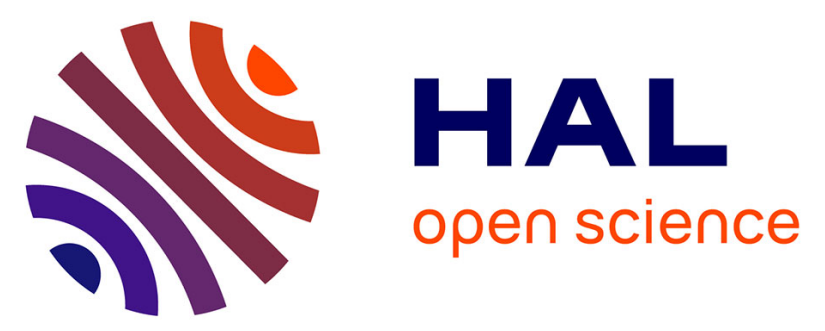

\title{
THE MASSTIGE PARADOX IN CHINA: A BUSINESS MODEL INNOVATION OPPORTUNITY FOR INDEPENDENT LUXURY COMPANIES?
}

Philippe Chereau, Jonas Jonas Hoffmann, Isabella Soscia

\section{- To cite this version:}

Philippe Chereau, Jonas Jonas Hoffmann, Isabella Soscia. THE MASSTIGE PARADOX IN CHINA: A BUSINESS MODEL INNOVATION OPPORTUNITY FOR INDEPENDENT LUXURY COMPANIES?. Global Fashion Management Conference, 2015, 2 (7), pp.264-269. 10.15444/gfmc2015.02.07.03 . hal-01948242

\author{
HAL Id: hal-01948242 \\ https://hal.science/hal-01948242
}

Submitted on 17 Dec 2018

HAL is a multi-disciplinary open access archive for the deposit and dissemination of scientific research documents, whether they are published or not. The documents may come from teaching and research institutions in France or abroad, or from public or private research centers.
L'archive ouverte pluridisciplinaire HAL, est destinée au dépôt et à la diffusion de documents scientifiques de niveau recherche, publiés ou non, émanant des établissements d'enseignement et de recherche français ou étrangers, des laboratoires publics ou privés. 
2015 Global Fashion Management Conference at Florence Proceedings: 264-269 (June 2015) http://dx.doi.org/10.15444/GFMC2015.02.07.03

\title{
THE MASSTIGE PARADOX IN CHINA: A BUSINESS MODEL INNOVATION OPPORTUNITY FOR INDEPENDENT LUXURY COMPANIES?
}

\author{
Philippe Chereau, SKEMA Business School - Sophia Antipolis, France \\ Jonas Hoffmann, SKEMA Business School - Université de Lille, France ${ }^{1)}$ \\ Isabella Soscia, SKEMA Business School - Sophia Antipolis, France
}

\begin{abstract}
Over the years, luxury has built-up a reputation as recession proof industry. Even though the industry growth has slowed down in the mid 2000s, luxury firms have managed to cope with economic contingencies and shortening traditional demand by widening their clientele base to prestige mass consumption - the "masstige clientele". Doing so, luxury firms have been pursuing a dual strategy by wooing aspirational consumers as well as their traditional elite customers, thus managing the challenge of handling both a differentiation strategy based on scarcity and uniqueness, and increased volumes of sales. This has been a trend in mature markets such as Europe, the United States and Japan, but was significantly fostered by expanding into emerging markets. Sector specialists thus expect China to remain a major structural growth area in the medium term, where the number of both high-end clients as well as new aspirational consumers will substantially increase and influence firms strategy.
\end{abstract}

\section{The Masstige paradox}

Masstige is a quite recent phenomenon that appeared in late $90 \mathrm{~s}$ as a result of the combination of two contingencies. First, the emergence throughout the world of growing middle classes and their awareness of potentially accessible new types of well-designed, well-engineered, well-crafted, and often well-labeled products. These new classes, well-educated and travelled abroad, disposed from an annual income of $\$ 50000$ or more, which opened doors for accessing new types of products. Second, the need for luxury firms to retrieve the double-digit growth rate common since the 1970s by enlarging their customer base through more affordable entry lines. This has generated a process of "luxury democratization" named as "luxury for the masses", and the creation of a new market segmentation supporting the volume side of the business strategy of luxury firms (Silverstein \& Fiske, 2003). Indeed, besides accessible premium products that middle classes can acquired as there are low-ticket items such as Belvedere Vodka or Starbucks coffee, priced significantly higher the standard products of their category, or lower-priced versions of traditional luxury products, such as the Must label from Cartier or the Class A from Mercedes, the masstige category offers high-quality products at mass-market prices. Over the years, masstige is not a secret password anymore for becoming an influential luxury company and even traditional luxury brands that preserve the strict standard between high prestige and price premiums in order to maintain their brand's exclusivity are ready for the masstige movement. This evolution may be viewed by certain stakeholders in the sector, including clients, as a threat of their strategic positioning

\footnotetext{
1) jonas.hoffmann@ @skema.edu
} 
from the standpoint of the risk of dilution or banalization leading to a down-grading of the brand. This threat is all the more perceived as the masstige phenomenon has generated a new breed of luxury goods consumers. Beside the traditional brand-loyal 35-to-55-year-old wealthy clientele that still exists, new luxury clients are younger, less brand-loyal, more fashion oriented, and strongly stimulated to acquire luxury goods by the symbolic representation attached to such goods (Lipovetsky \& Roux, 2003). Consequently, luxury brands are now struggling with the dilemma of refocusing on mainstream elite clients to maintain their status associated with uniqueness, rarity, and distinction while searching for solutions to fight against the brand-switching attitude of new luxury clients.

Indeed, masstige emphasizes the dilemma between scarcity, which characterizes the essence of luxury, and the need for volume to finance ever growing investments dedicated to innovation in new products, new marketing methods or new organizational practices to capture clients. The development of masstige markets has been strongly supported by global brand policies in emerging economies. Only such fast growing markets can support the volume strategies of global or mega brands needed to absorb today's fixed operating costs to build-up, develop and capture client awareness: communication, promotion and advertising, collection development, fashion shows, sample collections, accessories, etc. (Chereau \& Meschi, 2010). Among emerging markets, China is going to be the world's largest luxury goods market in the five to seven years. Therefore every luxury brand is looking at this big cake, while some bigger fashion retailers are also "plotting a move" for this type of collaboration. A report from New York Times shows that the luxury market has maintained steady growth of $8 \%$ in 2011 compare with $7.5 \%$ in 2010. Additionally, Chinese consumers' behavior and luxury company's strategies have been silently changing during the financial crisis and post-crisis periods. For instance, a lot of wealthy customers in China now tend to purchase a real luxury product as an investment, and have become more careful before purchasing. Similarly, in order to satisfy consumers' thirst for accessible premium products, the fashion industry has started to launch masstige collaboration with dedicated diffusion lines. Still, the combination of differentiating innovation and increased volumes of sales highlights a critical organizational challenge for luxury firms as regards the efficiency of their business model. Today's issue for luxury firms is focused on articulating firm's activities to deliver efficiently a value proposition to both their traditional elite clientele and their newly acquired aspirational clients.

\section{A new leitmotiv in luxury: Business model innovation}

The term business model (BM hereafter) has been largely used in the managerial literature since the 90s. It generally refers to how a firm creates, delivers and captures value for customers and for itself by articulating different areas of its activities. Two different uses of the concept prevail. The first one can be seen as a static approach that emphasizes the "model" dimension of the term. It is used as a blueprint that conceptualizes the fit needed between the different activities that the firm deploys to generate value, and the related mechanisms for value creation. The second can be called a transformational approach, where the BM is viewed as a guide to address change and focus on innovation, either in the firm, or in the BM itself. In this perspective, a BM is developed and stabilized along the way through progressive refinements aiming at maintaining consistency between areas of activities or adapting to the environment. Both perspectives are in fact complementary as the elements of 
the $\mathrm{BM}$ - the resources and competences of the firm, its organizational system and the value proposition offered to the market - need to be permanently interacting in an adaptive process where each changing element impacts the others towards fit (Demil \& Lecocq, 2010).

BernsteinResearch (BernsteinResearch, 2009) reports that there are five main determinants of the luxury firm's performance: consistent high-quality of products, high-quality and appropriate coverage of distribution network, right pricing positioning, appropriate price promotion, and coherence in design theme. These key success factors are valid in mature markets as well as in emerging economies. Masstige has been challenging these ingredients for success by forcing luxury firms to rethink the way to articulate them. Doing so, luxury firms have entered a process of transforming their BM as regards the resources needed to address the new typology of their clients, the new value propositions to attract them, and the differentiated channels and the type of relationship to maintain their loyalty. Vuiton has fully entered this process of BM innovation through product diversification, and refocusing its sales strategy through directly-operated stores. According to the luxury luggage brand, rarity resides essentially in its network of exclusive wholly-owned stores, the only places where customers can access their famous products. This selective distribution policy was celebrated in July 2012 by the reopening of the Maison de Plaza 66, in Shanghai, for the 20th anniversary of the presence of the brand in China. BM innovation has also been an issue for other flagship luxury firms. Until recently, Hermès manufactured leather goods (particularly bags) to last as long as possible, with styling and a designer label that changed little. This strategy was to remain valid over the years, as Patrick Thomas, Hermès CEO quoted: "the company has no desire to become "masstige", a mass producer of prestige goods. Even though we do not grow as fast as we could, we do not want to waste our image by putting a big $\mathrm{H}$ on millions of bags" (Financial Times, October 7, 2009). However, in order to expand in the lucrative Chinese market where the French luxury firm lagged behind its competitors, Hermès has launched a new brand in 2009, called Shang Xia (meaning "topsy-turvy" in Mandarin). This Chinese brand included ready-to-wear and decorative arts inspired by Chinese culture and traditions of craftsmanship.

In fact, the masstige phenomenon has lead luxury firms to innovate in their BM in several directions where actual scarcity has been replaced by perceived rarity in order to match exclusivity DNA of luxury with the volume necessity (Catry, 2003). To this aim, luxury firms have entered a never-ending race of new product launches as well as innovation in their processes. In so doing, luxury brands can spread costly research and development investments dedicated to exclusive product features over larger volumes of commoditized extensions of the initial version. The product innovation policy conducted by luxury firms has often been supported by luring the best young design talents to their teams. Masstige has therefore led luxury firms to foster innovation on their most prestigious products, while expanding sales into new luxury segments, thus sending strong signs of perceived exclusivity to both traditional and new clients. The continuous investments of the fashion industry into haute couture pursue this dual marketing strategy. The infatuation for a luxury brand is all the more sustained that it regularly puts to the fore new versions of its iconic products as a proof of dedication towards its aficionados, either elite or masstige. The option of market expansion is also determinant. Firms such as Gucci or Armani have chosen to move down the luxury scale to reach a wider target population. They do so by 
creating more accessible lines of products either by simplifying collections that are successful in the top-class bracket or by creating brands that are completely independent of existing brands (e.g., the Emporio Armani brand, as opposed to Giorgio Armani) and by increasing the number of accessories (bags, shoes, belts, and small leather goods). For firms such as Armani, Prada, LVMH or Gucci, designer accessories provide easy access to the brand, and they develop the customer's feeling of belonging (e.g., the Prada "tribe," the Dior "family" or the Gucci "clan").

Similarly, perceived rarity is also supported by innovation in the ways luxury firms market their products and maintain clients' loyalty. In order to effectively manage exclusivity and volumes, luxury firms have rethought their distribution policy towards substantial investments into large networks of directly-operated stores, the one and only places where clients can find their cherished products in an elitist atmosphere that provides a unique shopping experience, to the detriment of franchises or independent stores. This particular distribution strategy allows closer monitoring of distribution quality, promotions, and commercial margins. But this requires very high investments, since, on average, it takes three years before a store breaks even. Furthermore, many luxury goods industry's specialists consider that with less than 150 stores in the world, a luxury firm cannot be profitable. Parallel to this relentless opening of directly-operated stores, luxury firms have entered the on-line sales phenomena. LVMH has pioneered by launching eLuxury.com in June 2000 and even though some luxury goods industry's specialists wonder whether luxury goods can be sold online, the positive financial results achieved by such sites are encouraging luxury firms to develop this new distribution and communication channel (Chereau and Meschi, 2010). Beside innovation in distribution, the masstige scarcity-volume dilemma has been addressed by new forms of communication between the brand and its clients. Luxury firms have largely invested in public relations, capturing support from opinion leaders and key fashion magazines, as well as social network and on-line communication. According to the New York University's Luxury Lab think tank (Socha, 2010), "Many prestige brands are already highly-regarded and well-known brands. Regardless, social media allows them to reach out to a younger base of customers. And even if the brands don't need the social media presence to up their name-recognition, having social media pages allows brands to guide the dialogue about their brands".

\section{Masstige in China: a successful proof of concept}

The Chinese luxury market has been booming over recent years. BernsteinResearch estimated that Chinese luxury consumption growth was driving around $7 \%$ of the global luxury marketgrowth in 2005, while it has provided almost $50 \%$ of total growth in 2008. Whereas early Chinese consumers had materially lower luxury and fashion brand awareness, the strong development of network of directly-operated stores has played an essential role in bringing brands to consumers as well as driving brand awareness and top-of-mind recognition. Similarly, luxury firms' development in China has also been supported by significant advertising and public relations campaigns, material expenditure to set up numerous flagship exclusive stores, and investments in developing new resources and competences by hiring and training capable local management teams. These were the necessary sunk costs needed to address the Chinese luxury market whose fast growth was deeply anchored in the masstige ingredients of both exclusivity and volumes. Today's development of Chinese luxury market shows the successful outputs of this masstige strategy. 
The collaboration of Alber Elbaz, creative director at Lanvin, with H\&M could build the best example of masstige. Although at the beginning, Elbaz had initially spurned invitations from H\&M to collaborate, he was finally seduced by the "democratic" element of the project. "We thought it was a very relevant move. High-street fashion is really becoming stronger and more important, and we were always doing high fashion and I thought it would be interesting to understand this market." he said. This substantial innovation in Lanvin's BM has enabled the luxury firm to raise new opportunities by educating younger consumers to the flavor of luxury, thus seeding Lanvin's differentiating positioning into future clients' mind. There was no mixed-up in the brand image of Lanvin and H\&M, but rather a cross-fertilization for both as according to Margareta van den Bosch (Socha, 2010), creative adviser at H\&M and the former head of design "The customer is clever, he or she wants the best of all things, and mixes and matches from all different kinds of offerings and brands. It's something that we encourage: Fashion should be about finding new ways to express yourself, at a reasonable cost."

Even though one size does not fit all, the Lanvin and H\&M cooperation in China might announce new forms of masstige business models in emerging countries. When considering Olivier Theyskens' contemporary collection for Theory, Stella McCartney's children's line for Gap, Mulberry's collection for Target or Karl Lagerfeld and H\&M performance, there seem to be new spaces for innovative business models where mass markets will create opportunities of win-win diversification for prestige brands. "It's funny for a person who has money to buy something inexpensive and it's great for a person with not so much money to be able to get something by a designer," said Karl Lagerfeld (Socha, 2010). The situation in China is that the majority of consumers can't afford premium luxury products, but have strong aspirations for entering the universe of luxury through more affordable products, perceived as exclusive. Therefore, there is little risk of brand dilution when luxury firms entre the Chinese market with an appropriate masstige business model.

\section{Luxury firms and masstige in China: New prospects of business model innovation}

China will remain a cornucopia for luxury firms as it gathers the ingredients of the virtuous cycle of luxury and fashion brands (Catry, 2003), i.e. fast growing segments of elite clientele as well as new aspirational clients, which supports the substantial investments in direct distribution networks and brand recognition communication; lower rental and management costs and thus increased EBIT per sales store, which in turn fosters scaling effects over the network of directly-operated stores; and booming of social networks and lead users' influence, which simultaneously leverages top-of-mind brand recognition and volumes of sales. Jing Daily (2010) reports that "the success of a luxury label in China has much to do with the connection between the brand and the status it confers. Even though luxury consumers in China are extremely sensitive to the exclusive prestige of the brands, they are becoming more educated and less status-obsessed. Although masstige lines provide less status, Chinese consumers are growing more appreciative of goods for their quality and style rather than the ability of their price tags to impress others." Therefore, China may be the perfect playground for luxury firms to grow without having to trading-off between rarity and volumes. On one hand, masstige clients will help luxury firms financing and nurturing their product innovation strategies with increased volumes of sales and 
field-based insights. On the other hand, when pursuing a masstige strategy, firms will enhance brand recognition and strengthen the basis for future premium customers.

Consequently, luxury firms in China should emphasize new models of business with different but still complementary value propositions aiming at capturing both elite clients with real exclusivity and customized premium offering, and aspirational mass clientele with perceived exclusivity. This will require new forms of face-to-face customer relationship anchored on unique shopping experience in proprietary sales spaces, as well as virtual one-to-one interaction with clients. This dual positioning will generate a dual stream of revenues based on differentiation attached to uniqueness, and extended lines of flagship products dedicated to brand awareness. Therefore, successful business models of luxury firms in China will likely be characterized by permanent innovation in practices devoted to developing scarcity through "exclusivities of the moment", and influencing market behaviors to strengthen brand universalism.

\section{Independent Luxury Companies and masstige in China: An opportunity?}

Given the changing consumer behavior in the Chinese market and the openness to new brands, this could represent an interesting opportunity. That being said, the ticket price for entering the Chinese market is getting more and more prohibitive. The goal of this project is to empirically analyze to which extent masstige could be a business model innovation opportunity for independent luxury companies in China. Data collection will consist of multiple case studies with independent European luxury brands based in China.

Keywords: business model, masstige paradox, independent luxury companies, business model innovation, customers in China

\section{References}

Silverstein, MJ, N Fiske (2003), Luxury for the masses, Harvard Business Review, April.

Lipovetsky, G, E Roux (2003), Le luxe éternel: De l'âge du sacré au temps des marques, Gallimard, Le Débat, Paris.

Chereau P, PX Meschi (2010), Strategy and Value Creation of the European Luxury Firms, Centrale des Cas et des Media Pédagogiques

Demil, B, X Lecocq (2010), Business model Evolution: In search of dynamic consistency, Long range Planning, 43, 227-246.

BernsteinResearch (2009), European Luxury Goods at a Crossroads.

Catry B (2003), The great pretenders: The magic of luxury goods, Business Strategy Review, 14 (3), 10-17.

http://style.time.com /2013/08/01/ study-finds-facebook-holds-most-social-media -power-among-luxury-brands (2013), retrieved 2 January 2015.

Socha M (2010), A Bigger Crowd in Fashion Shift, Designers Go Masstige, Women's Wear Daily.

http://www.jingdaily.com/what-does-masstige-mean-for-china/ (2010), retrieved 2 January 2015. 